\title{
Educação Científica do Campo: uma Proposta Formativa e Curricular de Educação Científica para as Licenciaturas em Educação do Campo
}

\author{
Rural Science Education: a Curriculum Proposal for Field-Based Teacher \\ Training Programs
}

\author{
(1) Josiane de Souza, ${ }^{[0}$ Fernanda Ostermann, ${ }^{[0}$ Flavia Rezende
}

\begin{abstract}
Palavras-chave Resumo Neste trabalho buscamos perspectivas teóricoEducação Científica; metodológicas para embasar uma concepção da educação científica Educação do Campo; Análise Bakhtiniana; Currículo; Formação Docente. para a formação nas licenciaturas em educação do campo. Apoiadas na filosofia da linguagem de Bakhtin, partimos de uma retomada histórica das áreas de educação em ciências e de educação do campo, no contexto brasileiro, para chegar a uma compreensão qualitativa de como essas áreas se desenvolveram e com quais vozes dialogaram ao longo de sua história. Na sequência, apresentamos uma revisão de trabalhos acadêmicos produzidos pela área de educação em ciências que se voltam para a educação do campo. A partir dessa revisão e da compreensão histórica das áreas, elegemos a perspectiva crítica como voz comum entre os pesquisadores em educação do campo e alguns pesquisadores da educação em ciências. Seguindo esta direção, assumimos a racionalidade crítica para formação docente e nos apropriamos do modelo de docente intelectual crítico (Contreras, 2012) para delinear uma concepção híbrida do professor de ciências no âmbito da educação do campo. $\mathrm{O}$ ensino de ciências no currículo das licenciaturas em educação do campo foi idealizado a partir das vozes críticas da perspectiva curricular (Silva, 2017) que aproxima ideias de Paulo Freire à abordagem CTS. Concluímos a proposta com as vozes de Boaventura de Sousa Santos e de Hugh Lacey, que contribuem para a revisão da concepção de ciência a ser incorporada em nossa proposta de educação científica do campo.
\end{abstract}


Keywords Abstract In this paper, we discuss theoretical and methodological Scientific frameworks that can provide a basis for conceptualizing scientific Education; education for ruraleducation teacher preparation programs. Supported Rural Education; by Bakhtin's philosophy of language, the study will begin with a brief Bakhtinian historical overview of science education and rural education in the Analysis; Brazilian context, followed by a qualitative comprehension of how Curriculum; these areas developed and what were their influences throughout Teacher Training. history. Next, we present a literature review of articles on science education focused on rural education. From this review and from the historical understanding of these fields of knowledge, we chose the critical perspective as a common link among researchers in rural education and some researchers in science education. Based on critical rationality, we used the critical intellectual model (Contreras, 2012) to outline the training of a science teacher in the scope of rural education. Finally, we designed a curriculum proposal based on the critical aspects of the curricular perspective (Silva, 2017) that brings Paulo Freire's ideas closer to the STS approach. We concluded our proposal with Boaventura de Sousa Santos's and Hugh Lacey's approaches, which contribute to review the concept of science to be incorporated into rural scientific education in teacher training programs.

\section{Contexto histórico: a educação do campo e a educação científica no Brasil}

Enquanto seres vivendo em sociedade, somos todos constituídos pela História, pois ela engendra os acontecimentos, os discursos e as ideologias do presente. Esta percepção é assumida pela Filosofia da Linguagem quando Bakhtin $(2009,2011,2015)$ concebe nossos enunciados como irremediavelmente relacionados com outros enunciados, sejam contemporâneos ou do passado. Nessa perspectiva, encontrar caminhos que auxiliem na elaboração de uma proposta de aproximação discursiva entre a educação científica e a educação do campo, objetivo deste trabalho, requer a compreensão das trajetórias históricas percorridas por essas áreas. Assim, procuramos uma compreensão qualitativa de como essas áreas se constituíram, quais seus principais referenciais, objetivos e conquistas, identificando pontos de convergência e divergência que sinalizem possibilidades e limites para desenvolver esse estudo, que se volta para a formação docente em ciências no contexto das licenciaturas em educação do campo.

Entre as décadas de 1930 e 1950, a educação rural não se configurava enquanto área de conhecimento, mas as escolas rurais já existiam e formavam cidadãos por todo país. Após a crise de 1929, o Brasil passou por um movimento de industrialização, que segundo Vendramini (2013) fez com que grande parte da população rural fosse deslocada para as cidades, formando uma massa de trabalhadores disponíveis para o capital. Esse 
processo migratório levou a um movimento para educar, nos moldes da educação urbana, os povos que permaneceram nas zonas rurais, com o intuito de se superar a figura do camponês ignorante e avesso ao progresso, o que se constituía, segundo a autora, em um preconceito a respeito do povo rural. A visão preconceituosa firmada nesse momento histórico se manteve nas políticas públicas por meio da desconsideração de políticas voltadas especificamente à educação rural.

Nesse período, a ciência já se configurava como disciplina curricular e, segundo Krasilchik (2000), era voltada para a formação da elite, que traria prosperidade e renovação para o Brasil no pós-guerra. Em processo de industrialização, o país investia num modelo de educação para a formação técnica, em que a ciência era concebida de forma neutra (Krasilchik, 2000), gerada de forma dissociada de outras esferas da sociedade, como a economia, a cultura e a política. Os currículos escolares, influenciados por essa visão, acabaram sendo moldados de forma tradicionalista e racionalista, cujo objetivo deveria ser a transmissão de informações apresentadas de forma atualizada e organizada, para facilitar a aquisição de conhecimentos por parte dos alunos (Krasilchik, 2000). Em 1961, a Lei de Diretrizes e Bases ampliaria a participação das ciências no currículo, passando a valorizar o desenvolvimento do espírito crítico nos estudantes por meio do exercício do método científico (Krasilchik, 2000). Assim, na década de 60, por mais que o ensino de ciências e a educação rural se ressentissem da estratificação social vigente na história política e social brasileira, o ensino de ciências detinha respeito e era direcionado à pequena parte privilegiada da população, enquanto a educação rural, passava por constante sucateamento e desvalorização.

No período da ditadura militar, a educação rural e o ensino de ciências sofreram processos históricos diferentes. Foram criadas políticas de subordinação do campo à cidade e a agricultura familiar foi preterida em favor do agronegócio (Fernandes, 1999). Esse é um fato crucial para a história dos povos do campo no Brasil, já que a agricultura familiar, que dá identidade e condições de vida aos campesinos, foi renegada e banida do modelo econômico. Essa situação, que perdura até os dias atuais, sustentou o desenvolvimento da agricultura capitalista, aumentando a produtividade, mas, contraditoriamente, o desemprego, o que levou ao aumento significativo de trabalhadores sem-terra (Fernandes, 1999). Nesse mesmo período, o ensino de ciências continuou a privilegiar a neutralidade, a objetividade da ciência e padrões internacionais em detrimento das carências e dificuldades nacionais (Nardi, 2014).

Segundo Nardi (2014), entre as décadas de 1950 e 1980, o currículo de ciências brasileiro foi intensamente influenciado por fatores externos, principalmente, pelo acordo firmado entre a United States Agency for Development (USAID) e o Ministério da Educação e Cultura, que impôs uma transformação à sociedade brasileira no sentido de direcionar sua racionalidade. No contexto desse acordo, foram traduzidos e adaptados materiais didáticos dos Estados Unidos e da Inglaterra e realizados cursos para professores de escolas básicas e programas específicos para o ensino superior. 
Em 1971, a lei no 5.692 tornou obrigatória a educação profissionalizante no ensino médio, o que, segundo Krasilchik (2000), aumentou o abismo entre o ensino público e o particular, pois, enquanto as escolas particulares continuaram a preparar seus alunos para a educação superior, as escolas públicas tornaram as disciplinas científicas pretensamente preparatórias para o mercado de trabalho.

Nos anos 1980, período de luta pela redemocratização, os movimentos sociais ganhavam adeptos e eram paulatinamente engrossados, inclusive pelo Movimento dos Trabalhadores Rurais Sem Terra (MST), que se empenhava na luta por terra, teto e trabalho. Logo a educação passou a ser vista, por esse grupo, como importante para a mudança da sociedade e do sistema vigente. Contudo, em 1991, criou-se o Serviço Nacional de Aprendizagem Rural (SENAR), que visa à formação profissional do campesinato, tendo a classe patronal como responsável por sua organização e por determinar quais objetivos devem ser alcançados. Segundo Fernandes et al. (2004), sistemas como esse, acabam por reforçar relações capitalistas no campo, ao promoverem um desenvolvimento desigual, em um processo excludente, subordinado à lógica do capital.

Em 1996, é aprovada nova Lei de Diretrizes e Bases, que prevê que os alunos devem ser formados buscando a tríade cidadão-trabalhador-estudante. A lei determina que os estudantes sejam formados para mais que o mercado de trabalho e sejam críticos e participativos na sociedade, além de estarem aptos para seguirem os estudos em níveis mais avançados, se assim optarem (Krasilchik, 2000). Surgem nesse contexto, no âmbito da pesquisa em ensino de ciências, as perspectivas de alfabetização científica e de Ciência-Tecnologia-Sociedade (CTS), que já estavam em voga em outros países desde a década de 1970 (Santos, 2008). A perspectiva curricular CTS surge marcada pela crítica ao desenvolvimento científico e tecnológico (Aikenhead, 1997 como citado em Santos, 2008, p. 111) após o agravamento dos problemas ambientais mundiais e diante de discussões sobre a natureza do conhecimento científico na sociedade. Logo, o ensino de ciências com enfoque CTS, segundo Santos (2008), tem como principal objetivo a promoção da educação científica e tecnológica dos estudantes enquanto cidadãos, auxiliando na construção de conhecimentos, habilidades e valores necessários para que possam tomar decisões e atuar na solução de questões que englobem ciência e tecnologia.

A LDB de 1996 marca a primeira vez na história das políticas educacionais brasileiras em que a educação rural é citada através de suas particularidades e essas, segundo o documento, deveriam ser respeitadas. Entretanto, a educação rural não é definida nesse documento, o que dá margem a interpretações e práticas diversas. Em 1998, na $1^{\text {a }}$ Conferência por uma Educação do Campo ${ }^{1}$, nasce o Movimento por uma Educação do Campo, que tem por base uma mudança na visão sobre o campo, seus sujeitos e as questões políticas, sociais, culturais e econômicas que permeiam esse espaço (Ribeiro, 2015). Esse movimento passa a conceituar o campo como um espaço

1 Inferimos que essa conferência demarque o uso da expressão "educação do campo" no lugar de "educação rural", e a institua como representativa de uma área de conhecimento. 
de democratização, de inclusão social, que projeta seus sujeitos como sujeitos de história e de direitos (Arroyo et al., 2004). Essa mudança paradigmática é demarcada discursivamente pelo abandono do termo "rural" e utilização do termo "do campo" e os povos do campo passam a ser representados por, além dos camponeses, posseiros, pescadores artesanais, lavradores, diversas categorias extrativistas, ribeirinhos, quilombolas, povos indígenas etc., ou seja, todos que possuem uma identidade comum dada pela racionalidade camponesa (Michelotti, 2008). Ainda em 1998, os povos do campo conquistam o Programa Nacional de Educação na Reforma Agrária (Pronera), o que se constituiu em um importante passo para a libertação e valorização do meio rural (Caldart, 2012). O Pronera foi responsável pela promoção de cursos de ensino fundamental, médio, técnico profissionalizante e superiores aos assentados e assentadas.

Nos anos 2000, o Movimento por uma Educação do Campo ganha força sob os governos progressistas e a educação do campo é então ressignificada, deixando de ser uma cópia dos modelos urbanocentrados (Arroyo, 2012). Esse projeto inclui os excluídos, aumenta as oportunidades de desenvolvimento das pessoas e avança na produção centrada em uma vida mais digna para todos e respeitadora dos limites da natureza (Arroyo et al., 2004). A educação do campo não é pensada apenas como luta pela educação, mas é também uma forma de lutar pela terra, pela reforma agrária, pelo direito ao trabalho, à cultura, à soberania alimentar e ao território (Caldart, 2012). Essa modalidade de educação, segundo Ribeiro (2015), está intimamente ligada ao enfrentamento do capital materializado no agronegócio e às diferentes consequências que este modelo de desenvolvimento representa.

Nesse mesmo período, caminhos mais progressistas começaram a ser trilhados por pesquisadores da área de educação em ciências ${ }^{2}$ e novas linhas de pesquisa surgem, como por exemplo, as abordagens que têm enfatizado o papel da cultura e do discurso no ensino de ciências. Abordagens críticas, que enfatizam o papel político da educação em ciências, ganham profundidade no contexto internacional (Tolbert \& Bazzul, 2017), contudo no cenário brasileiro grande parte da pesquisa em educação em ciências e da prática dos professores de ciências seguem enfatizando apenas o conteúdo científico, deixando de fora a relação com a sociedade na qual são produzidos.

Em 2010, o Movimento por uma Educação do Campo conquista o Procampo, que tem seu primeiro edital lançado e para o qual 33 instituições de ensino tiveram seus projetos aprovados, totalizando 3358 novas vagas em cursos de licenciatura em educação do campo. O resultado provisório de avaliação referente ao segundo edital do programa, lançado em 2012, conforme exposto no portal do $\mathrm{MEC}^{3}$, relaciona mais 45 instituições pré-aprovadas para a implementação de licenciaturas em educação do campo. Na Portaria no 72, de 21 de Dezembro de 2012, a secretaria apresenta as 44 instituições de ensino com propostas aprovadas para a implementação desses cursos.

2 Passamos a utilizar a expressão "educação em ciências" no lugar de "ensino de ciências" para demarcar a abrangência maior e consolidação dessa área de conhecimento nos anos 2000.

3 http://portal.mec.gov.br/pec-g/194-secretarias-112877938/secad-educacao-continuada-223369541/18784-

oferta-de-cursos-de-licenciatura-em-educacao-do-campo-procampo 
Desse conjunto, 11 estão localizadas no Sul, 10 no Nordeste, 9 no Norte, 8 no Sudeste e 6 no Centro-Oeste e 32 oferecem habilitações na área das ciências da natureza. Cada um dos cursos dispõe, em média, de 60 vagas por habilitação a cada ano, o que configura em torno de 1900 novos alunos de licenciatura em educação do campo cursando habilitações em ciências da natureza ou relacionadas a essa área.

Até aqui, identificamos influências políticas e sociais específicas que impactaram a história da educação em ciências e da educação do campo, apesar de ambas as áreas terem sofrido influências mais amplas do mesmo modelo político e econômico. Enquanto a história da educação em ciências tem sido marcada desde sua origem pela aproximação com as ciências da natureza, que sempre mantiveram prestígio no modelo capitalista de sociedade, a história da educação do campo se constituiu em sua origem por um conjunto de movimentos sociais que impulsionaram políticas educacionais avessas a esse modelo econômico. Talvez essa seja a maior tensão que devemos levar em conta ao tentar aproximar as duas áreas, pois é a partir dela que nascem as maiores contradições, pois enquanto uma é o reflexo da luta de movimentos sociais e sofreu forte sucateamento e depreciação na maior parte de sua história, a outra é reflexo de uma prática liberal e sempre, apesar das diferenças de perspectiva, manteve seu prestígio frente a sociedade, se adaptando ao modelo político e econômico vigente. Essa diferença histórica precisa ser levada em consideração neste trabalho, que vai tentar produzir uma aproximação entre essas áreas.

Essa breve reflexão mostrou que a educação do campo e a educação em ciências percorreram trajetórias históricas diferentes e que praticamente não se cruzaram. Entretanto, o crescente número de cursos de licenciatura em educação do campo e a relação desses cursos com o ensino de ciências tornam-se questões relevantes para a pesquisa em educação em ciências e para a formação dos docentes que vão atuar nesse cenário. Neste sentido, consideramos que nossa iniciativa de trabalhar nessa interface ganha relevância. Compreendemos que nosso objetivo inicial deve ser buscar formas de aproximação teórica e metodológica que tornem a educação científica significativa no contexto da educação do campo e apontem caminhos futuros no que diz respeito ao currículo e à formação docente nas licenciaturas do campo com habilitação em ciências da natureza.

Iniciamos esse diálogo por uma revisão de trabalhos da área de educação em ciências que intencionam aproximação com a educação do campo, buscando compreender por meio de uma análise bakhtiniana, como essas aproximações têm sido construídas. Em seguida, nos dedicamos ao estudo de uma concepção de formação docente que consideramos adequada às licenciaturas em educação do campo. Para isso, partimos das vozes dos estudiosos da educação do campo e encontramos, no modelo de formação docente baseado na racionalidade crítica, uma perspectiva que se harmoniza com essas vozes. Apropriamo-nos então, da construção teórica de José Contreras (2012), que propõe o modelo de docente intelectual crítico para aprofundar a concepção de formação do professor de ciências no âmbito da educação do campo. O próximo passo 
foi delinear um currículo para as licenciaturas em educação do campo que se alinhasse com essa concepção. Partimos então, novamente, de um diálogo com vozes de autores da área de educação do campo sobre o currículo da formação docente, que nos levou aos fundamentos das teorias críticas de currículo (Silva, 2017).

No âmbito da educação em ciências, esse quadro teórico nos levou às vozes da perspectiva que aproxima as ideias de Paulo Freire à abordagem CTS e às vozes de Boaventura de Sousa Santos e de Hugh Lacey, que contribuem para a revisão da concepção de ciência a ser incorporada nas perspectivas curriculares para a formação docente no âmbito da educação científica do campo. Na seção final ressaltamos os principais pontos da proposta e discutimos desafios postos à educação do campo e à educação científica do campo, no contexto sócio-político atual.

\section{A educação do campo na voz da literatura em educação em ciências}

Esta seção reúne revisões da literatura realizadas em dois momentos. No primeiro, realizamos uma análise mais abrangente, que incluiu a revisão de artigos internacionais ${ }^{4}$ (Souza et al., 2020) e, no segundo momento, analisamos trabalhos mais recentes (Souza, 2020), complementando o primeiro conjunto.

Ambas as revisões foram realizadas nos periódicos nacionais de educação em ciências da área de Ensino, classificados no Quadriênio 2013/2016 do Qualis Capes, no estrato A1 e A2, abrangendo o período de janeiro de 2009 até setembro de 2020 . Utilizamos os extratores educação do campo e educação rural. Recorremos a um dispositivo analítico (Veneu et al., 2015), que leva em consideração, principalmente, dois aspectos da teoria de Bakhtin: o primeiro é que a análise dos fenômenos linguísticos deve ser feita tendo em vista as condições concretas em que eles se realizam, e o segundo, que a unidade de comunicação verbal é o enunciado, em oposição às unidades da língua, tais como a frase e a oração. Consideramos cada artigo como um enunciado, visto que, por ser um discurso escrito, sua conclusibilidade se dá pela conclusão do artigo.

Inicialmente, realizamos a leitura preliminar dos artigos, com o objetivo de identificar seus elementos linguísticos e fazer uma articulação prévia entre o material linguístico (estilo, construção composicional, conteúdo temático, relação com o falante e outros participantes, conclusibilidade), o objeto de estudo e os conceitos bakhtinianos. $\mathrm{O}$ conceito de voz abrange a escrita e as impressões, o conhecimento adquirido ao longo da vida e as visões de mundo do sujeito, ou seja, a perspectiva que se assume sobre o mundo. O discurso surge num determinado momento histórico em um meio social determinado, tocando milhares de linhas dialógicas vivas envoltas pela consciência sócio-ideológica, que participam ativamente do diálogo social (Bakhtin, 2015). Nosso discurso é então, pleno de palavras dos outros, que trazem a sua expressão, o seu tom valorativo que assimilamos, reelaboramos e reacentuamos conforme nossas intenções

4 Encontrados a partir dos extratores rural education, educación rural e educación del campo. Optamos por não comentar os artigos internacionais aqui, pois preferimos construir uma continuidade entre os dois momentos da revisão. 
(Bakhtin, 2011). A apropriação das palavras dos outros pode gerar processos complexos de assimilação, que geram novos discursos que não são a simples coexistência de duas linguagens mas a criação, a partir de linguagens diferentes, de uma nova forma de enunciar, denominada de hibridismo (Bakhtin, 2015). Esse processo é caracterizado por "um enunciado que pertence, pelos seus marcadores gramaticais (sintáticos) e composicionais, a um só falante, mas que realmente contém misturados em seu interior dois enunciados, duas maneiras de falar, dois estilos, duas 'linguagens', dois sistemas de crença semânticos e axiológicos” (p. 84). Esse conceito é importante para nossa análise, já que esperam-se encontrar processos discursivos que efetuem a aproximação entre a educação do campo e a educação em ciências.

Na próxima etapa da análise é realizada uma investigação do contexto extraverbal e de seus vários elementos, destacando-se o momento social e histórico em que ocorre ou a que se refere o discurso. Para Bakhtin (2009), todo signo linguístico vê-se marcado pelo horizonte social de uma época e de um grupo social determinados. Esse horizonte faz parte do contexto extraverbal e é composto por todas as relações sociais, culturais, políticas e econômicas, que permeiam o espaço-tempo daquele enunciado e do próprio enunciador. Neste sentido, consideramos os elementos históricos das áreas de educação em ciências e da educação do campo trazidos na seção anterior enquanto contexto extraverbal dos artigos.

A análise dos enunciados consistirá em articular os elementos linguísticos, o contexto extraverbal e os conceitos bakhtinianos ao objetivo do estudo de compreender como as vozes com que os autores dialogam constroem uma aproximação entre a educação em ciências e a educação do campo/rural.

Com base na análise dos três artigos nacionais encontrados, realizada no primeiro momento, inferiu-se que a educação científica no âmbito da educação do campo tem sido construída pela hibridização entre diferentes perspectivas. Cardoso e Araújo (2012) trazem vozes críticas sobre o currículo, o livro didático e a voz da educação do campo, indo assim ao encontro da visão crítica de autores da educação do campo. Costa et al. (2014) dialogam com a perspectiva crítica da educação do campo e também com a formação humana integral e a diversidade cultural rural. Por outro lado, Paniago et al. (2014) constroem seu discurso sem priorizar a voz da educação do campo, trazendo a voz da educação ambiental, visando à aproximação com a realidade dos alunos do campo.

No segundo momento, os quatro artigos encontrados também abordavam a educação do campo por meio de uma diversidade de perspectivas. Silva et al. (2019) realizaram uma revisão em periódicos relacionados à educação do campo, entre 2007 e 2016, e encontraram apenas dois artigos que se dedicavam ao ensino de ciências no âmbito da educação do campo. Esse resultado indicou que o diálogo não ocorre de lá pra cá, ou seja, da educação do campo para a educação em ciências. Halmenschager et al. (2018) realizaram uma pesquisa nas atas de eventos de educação em ciências e matemática entre 2009 e 2015, encontrando 19 trabalhos que se dedicavam à articulação da educação em ciências com a educação do campo, indicando que os eventos têm sido mais procurados para divulgação de trabalhos sobre esse tema. 
Locatelli et al. (2020) investigaram a utilização de atividades experimentais no contexto da educação do campo. Os autores se aproximam do conceito de educação do campo por meio da voz de Mônica Molina, uma das autoras que fundam a área acadêmica de educação do campo. Entretanto, não articulam em sua discussão ou conclusões, conceitos consistentes com essa voz. Seu discurso é construído por meio do diálogo com a perspectiva da aprendizagem significativa e da aprendizagem através da prática, silenciando possíveis diálogos com a perspectiva crítica ou com a realidade dos alunos.

Crepalde et al. (2019) utilizam como contexto de pesquisa um curso de licenciatura em educação do campo para propor a educação intercultural como possibilidade de aproximar a educação em ciências dos povos do campo. Os autores propõem um diálogo intercultural entre saberes no processo formativo de educadores do campo e a integração de conhecimentos tradicionais ao currículo de ciências, demarcando fronteiras e contextos de uso entre o tradicional e o científico.

O baixo número de artigos nacionais encontrado mostrou que embora a educação do campo esteja em pauta desde o lançamento dos cursos de licenciatura em educação do campo, em 2009, este tema ainda não foi eleito como objeto pelos pesquisadores da área de educação em ciências. Ressaltamos a apropriação da expressão "do campo" em contraposição à "no campo" por Cardoso e Araújo (2012), Costa et al. (2014) e Crepalde et al. (2019), no sentido de exprimirem a afirmação do campo como espaço cultural, histórico e socialmente singular, além de compartilharem a concepção de que o conhecimento dos povos do campo é fonte de empoderamento da comunidade. Por outro lado, Paniago et al. (2014) e Locatelli et al. (2020) veem o conhecimento do meio rural apenas como um elemento para motivar a aprendizagem do conhecimento científico, não se apropriando, assim, da expressão "do campo" com o sentido atribuído pelos autores da educação do campo.

Vimos, na seção anterior, que a história da educação do campo é constituída por vozes críticas ao status quo e que a criação e implantação do curso de licenciatura em educação do campo contaram com a participação ativa dos movimentos sociais, tendo seus preceitos e objetivos ligados às lutas dos sujeitos campesinos. A perspectiva crítica, além de se mostrar presente, ainda que de forma incipiente, nas construções discursivas de autores que buscam aproximar a área de educação em ciências à educação do campo é a voz que permeia a história da educação do campo e a criação e implantação do curso de licenciatura em educação do campo. Dessa forma, consideramos que as vozes dos autores que dialogam com a perspectiva crítica estão alinhadas às vozes da educação do campo e sinalizam caminhos promissores.

\section{A educação científica do campo: uma proposta formativa e curricular para a formação do docente do campo}

A relevância histórica dos movimentos sociais do campo por reinvindicação de políticas públicas educacionais que contemplassem suas realidades precisa ser considerada quando se busca desenvolver propostas para esse contexto. Neste sentido, 
nosso primeiro cuidado na construção da educação científica do campo será privilegiar estudos que se preocupem com o contexto da educação do campo, e assim como os movimentos sociais do campo, proponham a reinvenção das relações sócio-políticas que têm predominado no contexto social, científico ou educacional.

O breve histórico da educação do campo nos alertou para a ideia de que a educação científica do campo precisa ser algo novo e não uma reprodução da educação rural, ou seja, uma mera aplicação, no contexto do campo, da ciência moderna elaborada nas relações capitalistas. Entendemos que a educação científica do campo deve ser palco para a discussão de conteúdos técnicos hibridizados com questões políticas, econômicas, sociais e culturais, preconizando a formação de cidadãos críticos, capazes e interessados em atuar na sociedade. Nesse sentido, nos dedicamos ao estudo de referenciais críticos, construídos em discursos híbridos, que possam contribuir para uma concepção da formação de docentes no contexto da licenciatura em educação do campo.

\section{Concepção da formação docente para a educação científica do campo}

Antes do Procampo ser lançado, a formação dos educadores do campo ocorria, segundo Silva et al (2006), na própria prática e de forma coletiva, pois esses educadores, ao terem vínculo direto ou se identificarem com a cultura do campo, acabavam por se comprometer com as lutas dos povos do campo. Nesse processo, atuavam em diferentes espaços sociais e construíam sua formação no "cotidiano das diferentes atividades, a partir das relações estabelecidas em seu meio, nos diferentes processos desenvolvidos junto com os sujeitos com quem atuam" (p. 145). Esses sujeitos são lutadores e lutadoras que se empenham em construir uma nova vida para sua classe, através de processos educativos e formativos, que capacitam e preparam "para o trabalho, para a luta e para a vida, onde as pessoas são desafiadas a se construírem pessoalmente e coletivamente" (Silva et al, 2006, p. 149).

O Procampo institucionalizou práticas formativas voltadas para os povos do campo, levando às universidades, práticas, metodologias e princípios dos povos do campo para a formação de educadores. Nesse sentido, um aspecto trazido pela nova política formativa foi enfatizar componentes curriculares como economia, política, história, filosofia, sociologia, entre outros, que, em geral, estão ausentes dos cursos de licenciatura. Segundo Molina e Hage (2015), ao proporem esse currículo, as licenciaturas em educação do campo se comprometem com a oportunização de uma formação crítica, capaz de oferecer elementos que auxiliem os docentes na compreensão das "tensões e contradições que permeiam as relações sociais no território rural, contemporaneamente" com especial atenção aos "desafios impostos à permanência dos sujeitos camponeses nesse território a partir do avanço cada vez mais desenfreado do agronegócio” (p. 133).

A formação docente proposta pelo Procampo traz, assim, uma nova concepção da escola e do próprio campo, pois não é possível formar um educador do campo a partir de uma visão abstrata e preconceituosa dos trabalhadores do campo (Ribeiro, 2013). Caldart (2010) considera que essa nova escola mantém vínculo orgânico com os 
movimentos sociais e é comprometida com as lutas e desafios dos povos campesinos. $\mathrm{Na}$ concepção da autora, a formação do docente do campo deve possibilitar o debate político e social sobre as contradições do modo de produção capitalista e de como essas contradições se materializam no campo; sobre a luta pela reforma agrária; e sobre a lógica da produção/da vida camponesa (Caldart, 2010).

Os educadores do campo devem ser reconhecidos enquanto "sujeitos, pessoas e coletivos, que fazem parte de uma realidade específica, que são detentores de práticas, de conhecimentos, de valores, de concepções de campo, de educação" (Caldart, 2010, p. 138). Portanto, segundo a autora, sua formação deve ser omnilateral, levando em conta "todas as dimensões que constituem a especificidade do ser humano - vida corpórea material e desenvolvimento intelectual, cultural, educacional, psicossocial, afetivo, estético e lúdico - e as condições objetivas e subjetivas reais para seu pleno desenvolvimento histórico" (Frigotto, 2012, p. 267). Além disso, a formação dos docentes do campo deve privilegiar noções de respeito à diversidade, o que demanda conhecimento das principais formas de como essa diversidade se manifesta na realidade local (Silveira, 2011).

A formação proposta pelo Procampo, que está em harmonia com as proposições desses autores, se afasta assim, dos propósitos das políticas neoliberais e dá condições para que o docente compreenda criticamente sua própria prática, qualificando-o por meio da maior compreensão das teorias que têm orientado sua ação pedagógica (Molina \& Hage, 2015).

Os discursos dos autores que refletem sobre a educação do campo representam uma forma específica de ver o mundo, de pensar a vida e o bem estar do ser humano. Como as propostas de cursos aprovadas no âmbito dos editais do Procampo partiram, principalmente, de grandes universidades inseridas nas relações do mundo capitalista vigente, podem-se antever obstáculos. Um deles está relacionado ao fato de que os formadores dos futuros docentes do campo, em geral, têm pouca ou nenhuma relação com o ambiente rural e com os movimentos sociais, grandes responsáveis pelas conquistas dos cidadãos do campo. Assim, será preciso uma imersão dos docentes na realidade e vida dos campesinos para que compreendam suas necessidades.

De um modo geral, os autores da educação do campo trazidos nessa seção, apontam para uma formação docente comprometida com a elaboração da consciência crítica acerca das relações capitalistas de produção e de como essas relações impactam o campo e influenciam a vida dos povos campesinos. No entanto, na educação em ciências, a compreensão da escola como espaço de contestação social e luta ainda é incipiente, o que pode ser visto até pela baixa quantidade de artigos que se propõem a discutir a educação em ciências no âmbito da educação do campo. O que ainda permeia o discurso de muitos pesquisadores da educação em ciências é a visão cirúrgica que privilegia o ensino, como pode ser visto nos eventos da área, repletos de trabalhos sobre formas "inovadoras" de ensinar determinado conteúdo. Quase sempre, o objetivo parte da dificuldade no processo ensino-aprendizagem sobre aquele conteúdo e não do estudo de questões socioculturais que levem à importância de determinado conteúdo para a 
vida. Essa orientação é indispensável sobretudo na educação em ciências no contexto da educação do campo, como pode ser extraído até mesmo da resolução CNE/CEB n. 1 (2002), quando explicita que a identidade da educação do campo deve estar relacionada às "questões inerentes à sua realidade, ancorando-se [...] na rede de ciência e tecnologia disponível na sociedade" (Resolução CNE/CEB, 2002). Assim, nesse trabalho, estamos alertas no sentido de conter o pensamento conteudista, predominante na área de ciências, e dar espaço ao necessário olhar sociocultural para pensar a problemática da educação do campo.

Nossa leitura do contexto sócio-histórico das lutas em torno da educação do campo até à criação das licenciaturas, proposta pelo Procampo, nos levou a compreender a importância de se levarem em conta os processos políticos que permeiam projetos de pesquisa ou de ensino. No caso da formação de docentes para a educação do campo, foi possível enxergar os agentes do campo como sujeitos constituídos através de um longo processo de disputas políticas e pela afirmação do campo como um espaço com especificidades e valores diferentes daqueles comuns aos centros urbanos. Logo, não basta investirmos em formas de adaptar metodologias e estratégias de ensino já estabelecidas na área de pesquisa em educação em ciências para serem utilizadas por docentes formados nas licenciaturas em educação do campo, pois estaríamos velando as diferenças e subordinando o campo a uma adaptação desleal às referências do meio urbano. A história do campo e a forma como a sociedade campesina se organiza são constitutivos da identidade do campo e precisam ser incluídas, mirando uma intervenção sem imposição de visões urbanas tecnicistas e economicistas.

Para construir uma proposta de formação docente coerente com esses pressupostos, nossa posição é a de inventar um novo discurso formativo que hibridize as vozes da educação do campo e as da educação em ciências. Dentre as racionalidades teórico-metodológicas mais utilizadas na área de educação em ciências como base para o processo formativo - racionalidades técnica, prática, comunicativa e crítica (Duarte et al., 2009), a racionalidade crítica nos pareceu a mais alinhada aos princípios que pudemos extrair das ideias dos autores da educação do campo. Assumindo então essa direção, nos apoiamos na perspectiva crítica de José Contreras (2012), que enxerga a prática docente como ato político e social e visa à emancipação individual e social dos estudantes, para nos auxiliar na construção híbrida da formação docente para a educação científica do campo.

Contreras (2012) considera que a profissão docente passou por um longo período de proletarização e que seu profissionalismo foi deturpado no decorrer desse tempo. O autor propõe que ao falarmos da docência, utilizemos, em detrimento do termo profissionalismo, o termo profissionalidade, que é constituído por três dimensões: obrigação moral, compromisso com a comunidade e competência profissional. Essas dimensões podem ser interpretadas de diferentes maneiras, que geram três modelos docentes diferentes, dos quais nos interessa o intelectual crítico. 
A dimensão da obrigação moral se situa acima de qualquer obrigação contratual que possa ser estabelecida, já que está relacionada ao comprometimento dos docentes com o desenvolvimento dos estudantes como seres humanos. O ensino, segundo Contreras (2012), se torna um trabalho moral, pois compreende uma relação desigual que se sustenta na confiança de que as fraquezas dos estudantes nunca serão usadas contra eles, mas em prol deles, para seu desenvolvimento e aprendizagem. Embora os docentes não tenham intenção moral consciente na sua atuação diária, quase tudo que fazem tem consequências morais, já que todo docente traz consigo crenças, ideais, objetivos e preocupações pessoais que não são abandonados na sua prática.

A dimensão do compromisso com a comunidade pressupõe, segundo Contreras (2012), que os docentes devem ser autônomos em suas responsabilidades profissionais mas, ao mesmo tempo, devem ser publicamente responsáveis por elas. Nesse sentido, o docente e a comunidade são corresponsáveis pelo processo de ensino, pois ambos devem partilhar decisões que possam ser, de fato, representativas das necessidades locais. Para o autor, os docentes passam, assim, a assumir posicionamentos políticos comprometidos com a comunidade, já que vislumbram em sua sala de aula futuros cidadãos com variadas possibilidades sociais, culturais e profissionais.

Para que a obrigação moral e o compromisso com a comunidade sejam efetivados, é necessário que os docentes tenham competência profissional coerente com as perspectivas assumidas nessas dimensões. Para Contreras (2012), o sentido de competência transcende o puramente técnico e assume o de "competências profissionais complexas que combinam habilidades, princípios e consciência do sentido e das consequências das práticas didáticas” (p. 92), não estando atreladas unicamente a um livro didático ou a um currículo imposto. A obrigação moral do docente está direcionada à emancipação social e individual; o compromisso com a comunidade está atrelado à defesa de valores para o bem comum; e a competência profissional se relaciona à autorreflexão sobre as distorções ideológicas institucionais e à participação na ação política transformadora (Contreras, 2012).

Para conceber o docente intelectual crítico, Contreras (2012) constrói um discurso híbrido entre a perspectiva do docente intelectual transformador, de Giroux (1997), e a perspectiva da reflexão crítica. A perspectiva de Giroux (1997) pressupõe a visão de escola enquanto esfera pública e o conteúdo a ser ensinado não sendo apenas o legitimado por especialistas. Dessa forma, a escola se torna um lugar social, permeado por culturas, que promove o ensino de diferentes conhecimentos, e que estimula a análise crítica e a transformação social.

Giroux (1997) se apropria da voz de Gramsci (1971, como citado em Giroux, 1997, p. 186) para definir o intelectual enquanto intelectual radical, profissional que por meio do relacionamento com outros atores sociais busca desenvolver em seus alunos, a consciência política e de classe, e estimular lideranças para a luta coletiva. O docente intelectual transformador de Giroux (1997) tem como principal objetivo a formação de cidadãos conscientes sobre as relações de poder e capazes de lutar contra injustiças sociais, econômicas e políticas, além de problematizar o conhecimento através de um diálogo crítico que argumenta em prol de um mundo justo para todos. 
Para Giroux (1997), a formação desse docente deve ser crítica, baseada em discussões políticas, sociais, econômicas e culturais, além do currículo de formação ser tomado como uma política cultural, que enfatiza a importância do fazer social, cultural, político e econômico, apropriando-se da linguagem crítica para utilização de práticas de ensino que desmantelem e questionem as relações hegemônicas estabelecidas socialmente. Giroux (1997) dialoga, assim, com a perspectiva crítica do início ao fim de sua proposição, o que torna o modelo docente de Contreras (2012), que se apropria de sua concepção, coerente com a que estamos propondo para a formação dos educadores do campo.

Contreras (2012) agrega à concepção de intelectual transformador de Giroux (1997), a ideia de reflexão crítica. O autor parte do conceito de reflexão crítica de Habermas (como citado em Contreras, 2012, p. 186), mas o problematiza, aponta discordâncias e modifica o conceito. Para Contreras (2012), a reflexão crítica pode promover a emancipação social, pois auxilia na interpretação e transformação de processos de dominação, ao estimular os docentes a questionarem a estrutura institucional escolar e a perceberem as influências político-sociais dessa estrutura sobre suas práticas. A reflexão crítica ajuda, assim, no desvelamento do sentido ideológico da educação, inculcado através de práticas institucionalizadas e auxilia na manifestação de novas práticas educativas, libertando e emancipando os docentes de visões acríticas e permeadas por distorções ideológicas. A emancipação social, para o autor, se dá, portanto, tanto em caráter individual do docente, quanto em caráter social, na formação de alunos, por meio do diálogo intenso e contínuo com a comunidade e os movimentos sociais, na busca por justiça social, igualdade e bem-estar.

O papel ativo do docente intelectual crítico se alinha com o que imaginamos para a formação do docente comprometido com a educação científica do campo, pois representa o docente que procura construir o seu discurso em sala de aula por meio das vozes de diversos atores da comunidade, auxiliando na formação de cidadãos críticos interessados em atuar na comunidade. Essa concepção se mostra possível para a educação científica do campo, pois dialoga diretamente com o que os próprios autores da educação do campo pensaram ao elaborarem o projeto das licenciaturas. Segundo Caldart (2010), o curso surge da necessidade de modificar a situação discriminatória e injusta, do ponto de vista humano e social, que o sistema educacional do campo brasileiro vivia, além de se embasar na concepção de que o projeto de desenvolvimento do campo deve ser tomado como projeto de desenvolvimento do país.

A concepção do docente intelectual crítico se refere ao profissional como integrado à realidade e ativo em suas lutas e reinvindicações, tornando o espaço escolar continuidade da própria comunidade e não apenas uma parte que a compõe, de forma isolada. Entendemos que essa concepção docente seja ideal para pensar o docente do campo, assim como pode se alinhar a modelos educacionais diversos, não analisados neste artigo. No contexto da educação científica do campo, levará em conta toda a complexidade da dinâmica social campesina, as lutas sociais dos trabalhadores do 
campo e dialogará com os diversos atores envolvidos no processo pedagógico, cultural e político do campo. A formação dos docentes baseada na concepção do intelectual crítico promoverá assim, a reflexão crítica, potencializando a concepção do próprio docente enquanto agente que incentiva e efetiva a transformação da realidade. Para transformar tal concepção de formação docente em um currículo para as licenciaturas em educação do campo, buscamos uma concepção de currículo que correspondesse aos mesmos objetivos.

\section{Uma proposta curricular crítica para educação científica do campo}

O curso de licenciatura para educação do campo foi elaborado para atender à demanda de formação de professores posta pelos movimentos sociais do campo, tendo uma política pública que o fomenta e diretrizes que o embasam, alinhadas com os preceitos e compromissos assumidos pela área de educação do campo, já que contaram com a participação ativa de membros do Movimento por uma Educação do Campo.

Um dos maiores anseios dos movimentos sociais do campo em relação à formação de professores para o campo, antes da proposta do curso de licenciatura em educação do campo, era, segundo Arroyo (2012), a necessidade de reconhecimento e aprofundamento de saberes, valores e concepções de mundo e de educação, próprios do campo. Esses conhecimentos deveriam ser incorporados no currículo formativo, segundo o autor, em diálogo com as teorias pedagógicas, de organização escolar, na busca por um processo de ensino-aprendizagem que garantisse o direito à educação justa aos povos do campo. Para Arroyo (2012), havia ainda a necessidade de repolitizar o currículo, tornando-o mais crítico e incorporando o "conhecimento da história da produção de desigualdades e da história das relações políticas de dominação-subordinação da agricultura, dos povos do campo e de seus trabalhadores à lógica do capital" (p. 364), para dar maior densidade e radicalidade teórica aos currículos da formação docente. Essas propostas de mudança objetivavam uma formação docente plural, para uma atuação que garantiria a função política das escolas do campo, onde se incorporasse os saberes da terra, do trabalho, da agricultura camponesa e as especificidades de ser-viver no campo, nos currículos e propostas educativas (Arroyo, 2012). Para que isso se concretizasse, a formação docente não poderia ser ofertada de forma fragmentada, disciplinar, mas de acordo com a construção totalizante dos próprios movimentos sociais. A concepção do autor é a de que os movimentos sociais do campo constroem leituras do mundo, da sociedade, do ser humano, do campo, dos direitos e da formação estruturando as dinâmicas produtivas, sociais e culturais de forma articulada.

Com base nesse contexto de luta e nas demandas dos povos do campo, as bases curriculares das licenciaturas em educação do campo propõem ações capazes de formar para compreensão e atuação em diferentes espaços, tempos e situações, preparando os docentes para além da docência na área de conhecimento, para gestão de processos educativos escolares e gestão de processos educativos comunitários (Molina \& Sá, 2012). A sua constituição curricular traz, além dos componentes interdisciplinares relacionados 
às áreas, exercícios de trabalho pedagógico interdisciplinar, debates críticos sobre o currículo atual das escolas, participação em experimentações pedagógicas mais ousadas e estudos de questões locais atuais que facilitem a integração do trabalho escolar com os aspectos significativos da vida real de seus sujeitos (Caldart, 2010).

Tal concepção curricular, segundo Molina (2015), procura se afastar da concepção hegemônica para formação docente, que precariza e rebaixa a qualidade das políticas de formação, pois priva os futuros docentes de "amplos conhecimentos históricos, sociológicos, filosóficos, econômicos, capazes de lhes dar sustentação para uma leitura ampla dos processos sociais vigentes na sociedade brasileira" (p. 395). A consequência dessa formação é a atuação docente sem consciência desses processos, ficando a serviço da manutenção da lógica capitalista (Molina, 2015). As licenciaturas em educação do campo, alinhadas à concepção contra-hegemônica, buscam uma base curricular que contribua para a formação crítica dos educadores, "dando-lhes condições de compreender os modelos de formação do campo em disputa, como parte integrante da totalidade de projetos societários distintos, entre a classe trabalhadora e a capitalista" (Molina \& Hage, 2015, p. 138).

O currículo para formação dos docentes do campo também se afasta da concepção tradicional ao propor a formação por áreas do conhecimento, colocando a realidade dos povos do campo como objeto central de estudo. A proposta de formação por áreas, para gestão educativa escolar e comunitária, está alinhada às demandas sociais do campo, ao aproximar a realidade dos sujeitos da sua formação e práticas educacionais. O currículo da educação científica do campo para a formação docente, deve, portanto, concordar com todos os preceitos defendidos pelos autores do campo, além de propor perspectivas que concebam a ciência como não neutra e isolada das relações sociais, políticas, econômicas e culturais que permeiam seu processo de desenvolvimento. Vislumbramos então, a possibilidade de diálogo entre a perspectiva crítica de currículo e as áreas de educação em ciências e educação do campo a partir de três vozes: a proposta curricular CTS/Freire, a teorização sociológica de Boaventura de Sousa Santos e os conceitos da filosofia da ciência de Hugh Lacey.

O movimento CTS contribui com visões contra-hegemônicas acerca da ciência, da tecnologia e da sociedade, ao relacionar a esses conceitos valores ligados aos interesses coletivos, como os de solidariedade, de fraternidade, de consciência do compromisso social, de reciprocidade, de respeito ao próximo e generosidade, que são relacionados às necessidades humanas, e questionar a ordem capitalista que impõe valores econômicos em detrimento dos demais valores (Santos \& Mortimer, 2002). Nessa perspectiva, a ciência deve ser vista como não neutra e não apartada de questões sociais, culturais, econômicas e políticas, se afastando totalmente do positivismo e do cientificismo (Bazzo et al, 2003; Santos \& Mortimer, 2002). A tecnologia não deve ser vista apenas como mera aplicação científica, mas, deve ser compreendida em todos os seus aspectos - técnico, organizacional e cultural - e como algo a ser questionado do ponto de vista utilitário e técnico (Bazzo et al, 2003; Santos \& Mortimer, 2002). 
A perspectiva CTS traz também a visão de participação de todas as pessoas nas decisões sociais, já que prega o acesso de todos a informações e conhecimentos para que entendam que problemas sociais, antes tomados como naturais, podem e devem ter solução. E, além disso, que essa solução não depende apenas de mudanças na legislação, ou de ações governamentais mas, cada indivíduo pode ser protagonista nas mudanças que almeja para o contexto em que vive (Bazzo et al, 2003). Logo, a busca pela compreensão da dimensão social da ciência e da tecnologia está no centro dos estudos da perspectiva CTS (Bazzo et al, 2003), e é, justamente, a caracterização social dos fatores responsáveis pelas mudanças científicas o que torna esses estudos tão inovadores.

Em um esforço de redirecionar a perspectiva CTS para a realidade latinoamericana e para o ensino de ciências, Auler (2002, como citado em Auler, 2007, p. 175) propôs aproximar as ideias de Paulo Freire ao movimento CTS, inicialmente para instigar a democratização dos processos decisórios acerca das questões sociais que envolvem Ciência e Tecnologia. Porém, julgamos importante ter a consciência de que os contextos de surgimento do movimento CTS e das ideias de Paulo Freire são diferentes. Enquanto o primeiro, segundo Roso et al. (2015), é originado na Europa e nos países ditos de primeiro mundo ou desenvolvidos, Paulo Freire tem seu contexto de estudo enraizado na América Latina e África, regiões oriundas de um passado colonial e compostas por países ditos de terceiro mundo, ou, em desenvolvimento. Roso et al. (2015) apontam que uma forma de atenuar as discrepâncias teóricas entre as concepções do movimento CTS e as de Paulo Freire seria por meio da apropriação do Pensamento Latino-Americano pela abordagem CTS, o que vem sendo denominado com a sigla PLACTS. O produto desse desdobramento do movimento CTS se caracteriza por questionar as consequências sociais do desenvolvimento científico e tecnológico ou seus antecedentes e tem como orientação o enfrentamento de problemas locais/regionais, problematizando as políticas científico-tecnológicas dos países da América Latina estruturadas numa relação de subserviência em relação a demandas dos países de primeiro mundo (Rosa \& Auler, 2016). Esse olhar é necessário para que não incorramos no risco de utilizar uma teoria pensada para um contexto diferente, inculcando visões que possam desmerecer, oprimir ou silenciar as questões oriundas do contexto da educação do campo. Estando nossa proposta curricular referenciada ao hemisfério sul, especificamente a um país latinoamericano em desenvolvimento, entendemos que o PLACTS perpassa sua construção. Apesar de, neste trabalho, não aprofundarmos contribuições específicas do PLACTS para a educação científica do campo, estamos cientes de que todas as questões que a permeiam constituem um pano de fundo para sua elaboração.

A perspectiva freireana, por sua vez, institui a concepção de educação problematizadora, que é em sua essência dialógica e torna educandos e educadores investigadores críticos, retirando do educador o papel de impositor de conteúdos. Freire (1977) também concebe os indivíduos como seres históricos e explora essa historicidade, fazendo emergir consciências críticas acerca da realidade, que acabam desvelando situações, antes vistas como irremediáveis. O autor desenvolve a Pedagogia 
do Oprimido, que propõe práticas educativas desenvolvidas e articuladas a partir da realidade dos sujeitos, tornando-os ativos no processo de libertação. O currículo freireano é desenvolvido por meio da concepção da educação problematizadora num processo intelectual e político que exige reflexão e ação transformadoras, em que a própria experiência dos educandos se torna a fonte primária de temas geradores que constituirão o conteúdo programático. Ou seja, os conteúdos nascem e se desenvolvem da vivência dos educandos e da sua interação com o professor. Assim, ao aliar o currículo CTS à pedagogia freireana, necessariamente se instiga a formação de alunos críticos que lutam pela mudança e fogem do imobilismo, já que as situações reais são colocadas como passíveis de mudanças em ambas as concepções.

Para que a educação científica do campo cumpra com as intenções da perspectiva CTS/Freire, todos os agentes da comunidade devem ser inseridos na construção do conhecimento científico, que deve ser hibridizado com as questões sociais, políticas, econômicas, ambientais e culturais pelo qual a comunidade tem apreço e necessidade de dialogar. Quanto mais subsídios tiver e melhor compreender o contexto e demandas locais, melhor o docente formador estará preparado para analisar, escolher questões de estudo que retratem contradições sociais e compreender quais são as situações-limite, legitimadas nos discursos da comunidade, que poderão definir os temas geradores do trabalho. Outro momento importante da perspectiva freireana, que pode auxiliar no processo de hibridização proposto é a redução temática, que demandará mais estudos e pesquisas do docente formador ou da equipe formadora, pois objetiva o aprofundamento das situações-limite através de estudos que busquem as relações dessas com as questões científico-tecnológicas.

Freire já tem sido indicado como uma possibilidade na relação interdisciplinar proposta para as licenciaturas em educação do campo. Brick et al. (2014) ao serem desafiados, enquanto pesquisadores da área de educação em ciências, a contribuírem para a materialização dos princípios da educação do campo, dentre as diversas perspectivas já desenvolvidas para o ensino de ciências, destacam a perspectiva desenvolvida a partir da educação freireana. Os autores afirmam que essa perspectiva pode ser significativa no contexto da educação do campo porque Freire "revoluciona a prática educativa ao conceber uma educação popular que tem como suporte filosófico-ideológico os valores e o universo sócio-linguístico-cultural dos povos do campo" (Brick et al., 2014, p. 24). Para esses autores, a perspectiva freireana pode contribuir para a formação de docentes numa perspectiva libertadora, articulando pesquisa, ensino e extensão, por meio da investigação temática, buscando consolidar as relações entre as áreas de educação em ciências e educação do campo. Ainda que nossa abordagem à perspectiva freireana se dê no seu diálogo com o movimento CTS, consideramos que nossa proposta é coerente com os pressupostos de Brick et al. (2014), e que ampliamos as ideias iniciais desses autores, que vislumbraram, para aproximar as áreas, a voz de Freire como uma possibilidade promissora. 
A teorização sociológica de Boaventura de Sousa Santos também nos pareceu valiosa para compor a educação científica do campo, na medida em que busca desenvolver uma concepção de consciência e dignidade humanas baseada numa epistemologia que privilegia os povos do sul global. O autor critica a forma com que a sociedade se organiza e se desenvolve atualmente, fundamentada na visão de mundo colonialista dos países do norte global. Nessa relação, os países do sul são submetidos a políticas e organizações sociais hegemônicas, de forma velada, que os levam a acreditar que suas culturas não têm importância e, portanto, devem ser oprimidas. As ideias de Santos (2007) são desenvolvidas para subverter essa lógica, ao combaterem o silenciamento das culturas locais - neste texto, representados pela cultura dos povos do campo - e apontar as diferenças, mostrando que não há um padrão cultural superior que deva ser seguido. Nessa perspectiva, a educação científica do campo pode ser construída por meio de uma proposta curricular que busque romper com as monoculturas - do saber e do rigor, do tempo linear, da naturalização das diferenças, da escala dominante e do produtivismo capitalista - que são modos diferentes de produzir ausências, silenciar indivíduos e excluir povos inteiros do direito à educação. $\mathrm{O}$ autor sugere substituir as monoculturas pelas ecologias - dos saberes, das temporalidades, do reconhecimento, da transescala, das produtividades - transformando os objetos ausentes em objetos presentes.

Em nossa proposta, as ecologias, citadas acima, levarão em consideração as especificidades da realidade local, fomentando lutas e valorizando a cultura do povo em contexto. A ciência, nessa perspectiva, também ganha novos contornos, menos técnicos e ocidentalizados, sendo privilegiada a discussão da aplicação edificante da ciência na sociedade. Santos (2018) indica, para o processo de ensino e aprendizagem, a Pedagogia do Conflito, em que a troca de conhecimento se dá de maneira a emancipar os estudantes e professores, promovendo conscientização quanto às escolhas do passado que promoveram as situações de submissão e colonialismo do presente, visando sua desnaturalização. Dessa forma, é fomentada a formação crítica do cidadão, que suscitará sua participação nas decisões sociais de seu contexto e principalmente, o enfrentamento daquelas situações danosas à sua realidade. A educação científica do campo, se pautada por essa concepção, buscará compreender genuinamente as relações sociais de colonialismo, contra as quais os movimentos do campo lutam há anos, e subvertêlas através de seu questionamento, impedindo silenciamentos e valorizando culturas e conhecimentos locais.

A Pedagogia do Oprimido (Freire, 1977) e a Pedagogia do Conflito (Santos, 2018) buscam a emancipação dos sujeitos através da voz crítica, por diferentes abordagens que dialogam entre si. Freire (1997) afirma que os processos educativos devem subverter a lógica da opressão, possibilitando aos sujeitos se reconhecerem como oprimidos e reconhecerem a nocividade das situações de opressão, superando a contradição entre se libertarem e se tornarem opressores, através de temas extraídos e articulados às suas realidades. Santos (2018) propõe um processo educativo emancipatório, que confronte conhecimentos, não os hierarquizando e apresente as situações reais vividas como 
construções históricas, geradas e naturalizadas pelo colonialismo. Podemos afirmar que mostrar situações reais, a que os sujeitos são submetidos diariamente, é um ponto de encontro entre as vozes de Freire (1977) e Santos (2018) e, ainda que um proponha a prática educativa através de temas geradores e o outro através do conflito entre os diversos saberes, ambos constroem discursos que buscam a libertação e emancipação dos sujeitos, vozes que dialogam com as lutas que os povos do campo têm assumido ao longo de sua história. Portanto, a educação científica do campo deve também assumir um posicionamento de questionamento das relações sociais estabelecidas e naturalizadas, sendo a Pedagogia do Oprimido e a Pedagogia do Conflito abordagens apropriadas para tal.

A perspectiva filosófica de Hugh Lacey (1998, 2000), buscando mostrar que o desenvolvimento da ciência é permeado por valores sociais e morais, além dos valores cognitivos, desestrutura a visão elitista da ciência, possibilitando um maior diálogo entre os conhecimentos científicos e os comuns. Lacey (1998) afirma que a educação científica não deve se dedicar apenas a ensinar teorias e metodologias já estabelecidas e aceitas, mas deve desenvolver a autoconsciência crítica sobre o caráter da atividade científica, suas aplicações e as escolhas com que os responsáveis por seu desenvolvimento se defrontam. Para o autor, a ciência e a educação científica deveriam estar relacionadas à concepção de desenvolvimento autêntico, que não prioriza o progresso material ou o crescimento econômico, mas a reconquista, pelos povos desfavorecidos, da capacidade humana de agir e determinar as estruturas de suas vidas, integradas ao crescimento econômico. O desenvolvimento autêntico centra suas práticas nos movimentos sociais, visando ao entendimento entre a ciência moderna e os conhecimentos populares, que possa auxiliar no atendimento às necessidades, interesses e valores autênticos do povo, subvertendo a opressão dos valores capitalistas.

Através dessa leitura, pode-se trazer à tona a valorização e a escuta das demandas locais, incorporando ao currículo a crítica à ciência moderna e promovendo o desenvolvimento autêntico. Dessa forma, a educação científica do campo estaria balizada por um novo paradigma acerca do desenvolvimento científico e social, que desfocaria os valores capitalistas e valorizaria as questões locais. Cria-se assim, um espaço de formação crítica, que questiona as relações capitalistas e a racionalidade técnica.

Essa perspectiva dialoga com as perspectivas freirena e de Boaventura de S. Santos, na medida em que também defende a interação com os conteúdos e valores das comunidades locais. Os docentes, de acordo com um diálogo entre esses autores, se tornariam mediadores entre os conhecimentos dos especialistas e as demandas apresentadas localmente, originando a hibridização das questões políticas, sociais, econômicas e culturais importantes para a comunidade com os conhecimentos científicos e técnicos.

Por meio de diferentes conceitos, as vozes que trouxemos defendem igualmente a relação de conhecimentos técnicos com questões sociais, políticas, econômicas e culturais, o questionamento das relações capitalistas hegemônicas, a rejeição à 
racionalidade técnica e ao cientificismo, preconizando a formação de cidadãos críticos, capazes de atuar e modificar os contextos em que estão inseridos. De certo, esses não são os únicos referenciais teóricos que poderiam balizar a construção do currículo que estamos propondo, mas, acreditamos que esse conjunto possa configurar um ponto de partida para futuros estudos que busquem desenvolver a educação científica do campo.

Procuramos compreender as vozes dos pesquisadores em educação do campo e trazer outras vozes que pudessem dialogar com elas no intuito de construir uma educação científica do campo para a formação de docentes no contexto das licenciaturas em educação do campo. Não buscamos, no entanto, esgotar as possibilidades para futuros estudos, pelo contrário. Procuramos construir uma base teórico-metodológica para a formação do docente intelectual crítico, que se traduz em um currículo que se afasta da racionalidade técnica, questiona a concepção capitalista que envolve o contexto do campo brasileiro, subverte os processos de silenciamento e opressão e contesta a visão de neutralidade da ciência. Essa formulação está alinhada com uma concepção de educação científica afastada das visões capitalistas urbanocêntricas e da racionalidade técnica, e que relacione conceitos científicos aos propósitos da educação do campo por meio de um discurso híbrido que estimule o pensamento e reflexões críticas, considerando a escola como palco para discussões políticas, econômicas, sociais e culturais. Esses propósitos estão alinhados à formação de cidadãos comprometidos com a crítica às relações de exploração existentes no campo e capazes de lutar pela subversão dessas relações. Esperamos que nossa reflexão instigue futuros estudos que busquem dar conta dos demais contextos de inserção da educação científica do campo.

\section{Síntese e contribuições da proposta}

Nosso trabalho foi motivado pela expressiva expansão dos cursos de licenciatura em educação do campo nas instituições públicas de ensino superior, com habilitações em ciências da natureza ou áreas afins. Das 44 instituições que possuem essa modalidade de licenciatura, 32 oferecem habilitações nessa área, configurando em torno de 1900 novos alunos cursando essas habilitações, nas licenciaturas em educação do campo, todo ano. Esse crescente número de cursos de licenciatura em educação do campo nos instigou a investigar a sua relação com a educação em ciências, do ponto de vista da pesquisa na área e da formação dos docentes que vão atuar nesse cenário. Julgamos fundamental iniciar pela tentativa de conceituar, o que denominamos de educação científica do campo, pois, ainda que a prática seja muito importante, ela precisa ser teoricamente fundamentada.

Para nossa construção propusemos o modelo do docente intelectual crítico para o docente comprometido com a educação científica do campo pois, compreender as relações sociais que envolvem a escola e o campo e procurar construir o seu discurso em sala de aula por meio das vozes de diversos atores da comunidade, auxilia na formação de cidadãos críticos interessados em atuar na comunidade. Essa concepção docente é fundamentada na ideia do docente intelectual transformador, que compreende as escolas enquanto esferas públicas democráticas, valoriza todo conhecimento que 
possa estimular a crítica e promover a transformação social. Esses conceitos dão apoio para que o discurso híbrido da educação científica do campo estimule o pensamento e reflexões críticas, considerando a escola também como palco para as discussões políticas, econômicas, sociais e culturais e que os conteúdos técnicos não são apartados dessas questões, mas permeados por elas. A formação dos docentes será assim, pautada pela perspectiva crítica, promovendo a reflexão crítica e potencializando a concepção do próprio docente enquanto agente que incentiva e efetiva a transformação da realidade.

Para compor essa concepção de formação docente, propusemos uma concepção de currículo que correspondesse a estes objetivos e que norteia a formação docente para a educação científica do campo, sem, no entanto, pretender esgotar possibilidades para futuros estudos. Encontramos alinhamento com a proposta curricular CTS/Freire, que, ao ressignificar as relações entre ciência, tecnologia e sociedade e assumir a educação problematizadora, desconstrói a racionalidade técnica, promove o questionamento das relações capitalistas e estimula a subversão dos processos de silenciamento e opressão que, normalmente, estão presentes nos currículos tradicionais.

$\mathrm{Na}$ discussão teórica proposta por Boaventura de Sousa Santos, encontramos a possibilidade de ressignificação da ciência, que afasta a visão de neutralidade, e na concepção de currículo estruturado através das ecologias, que dão voz e espaço a diversas formas de conhecimento, valorizando lutas e culturas locais. Ao buscar uma nova concepção de consciência e dignidade humanas, por meio de uma epistemologia que valoriza o sul global, o autor propõe a Pedagogia do Conflito como possibilidade de formação crítica e de emancipação para professores e estudantes. O discurso de Hugh Lacey, por sua vez, também dialoga com a perspectiva crítica, ao propor uma visão sobre a ciência permeada por valores, concebendo-a enquanto construção humana, suscetível a relações sociais, econômicas e políticas. A proposta do autor possibilita o diálogo entres os conhecimentos, valorizando e dando voz às demandas locais e ao desenvolvimento autêntico.

Entre as contribuições do trabalho para a área de educação em ciências, consideramos que o histórico que construímos, representa um avanço, na medida em que identificamos uma carência desse tipo de reflexão na literatura. Nosso trabalho também representa um avanço em relação às pesquisas sobre a educação do campo levantadas na literatura em educação em ciências. Julgamos ter ido além da apropriação da demarcação discursiva "do campo" em oposição a "no campo". Nossa proposta para a formação docente desenvolve um novo conceito (educação científica do campo), que, por meio da voz da perspectiva crítica e de uma revisão do conceito de ciência, elabora uma aproximação entre a educação em ciências e a educação do campo. Neste sentido, consideramos também uma contribuição relevante, o diálogo entre a perspectiva crítica de currículo e as áreas de educação em ciências e educação do campo, a partir das vozes da proposta curricular CTS/Freire, da teorização sociológica de Boaventura de Sousa Santos e da filosofia da ciência de Hugh Lacey. 


\section{Desafios à educação científica do campo}

A proposta para a formação de educadores do campo, construída no diálogo com vozes de pesquisadores da educação do campo e com uma linha de pesquisa da educação em ciências, expressa nossa concepção híbrida de educação científica do campo. Na prática, essas ideias demandarão muitos esforços e uma construção conjunta entre professores universitários, docentes do campo em formação e comunidades do campo. Nossos estudos chegaram a proposições que se apoiam no diálogo efetivo entre essas três esferas sociais que, apesar de distintas, devem buscar o mesmo objetivo ao se aliarem para compor a educação científica do campo. Os desafios e limitações devem surgir na aplicação prática de nossa proposta, pois demandará dos docentes universitários envolvimento com a realidade, com os movimentos sociais e com os próprios sujeitos do campo, na tentativa de efetivar o projeto da educação do campo dentro de uma instituição de formação que não foi pensada a partir dessa realidade. Apesar dos progressos em termos de políticas inclusivas e assistenciais, o projeto progressista para o qual estamos contribuindo ocorre dentro de uma universidade subordinada a políticas públicas e mecanismos avaliativos que concebem a instituição para a formação conteudista, o que representa um desafio.

Nossa proposta também exige que as comunidades do campo estejam abertas ao diálogo com essas instituições, para a construção coletiva do processo formativo, enquanto os docentes em formação serão demandados a serem mediadores na construção do diálogo entre a instituição e sua realidade particular. Será na elaboração prática, enfrentando demandas dos atores envolvidos na elaboração da educação científica do campo na formação docente que surgirão as limitações de nossa proposta teórica, que até então, se mostra como uma possibilidade promissora. Deixamos, como desafio para futuros estudos, a concepção de nossa proposta no contexto da prática.

Para além dos desafios institucionais e pedagógicos previstos, enfrentamos desde 2019, desafios que nos parecem muito mais graves e difíceis de contornar. Em 2012, quando foram idealizadas, as licenciaturas para educação do campo eram novidade no contexto nacional, com muitos concursos para provimento de cargo de docente nesses cursos, o que acabava colocando-as em evidência. Na época, vivíamos sob um governo que incentivava o respeito às minorias e à educação, através de políticas públicas, fomentos e outros posicionamentos discursivos que transmitiam a importância desses investimentos à população.

É justamente a partir da compreensão da construção discursiva da educação do campo no Brasil, que reconhecemos que os maiores desafios, atualmente, impostos a essa modalidade educativa - e a todas as outras -, são as políticas e discursos governamentais que minimizam e ridicularizam as minorias e enaltecem visões liberais que preconizam o capitalismo em detrimento do bem-estar do povo. Apesar do capitalismo ter sido nos últimos séculos o modelo econômico assumido pelo país e as relações trabalhistas e econômicas do agronegócio sempre terem pairado sobre o campo e sobre a luta dos povos do campo, o momento em que os movimentos sociais ganharam espaço e voz 
para propor o projeto da educação do campo, representou um avanço social e cultural relevante. Diante do atual governo, tememos um retrocesso severo, que, mesmo que não elimine todas as vitórias, faça com que a educação do campo venha a sofrer perdas de voz e de espaço.

Em 20 de Fevereiro de 2020, o presidente da república publicou o Decreto n ${ }^{\circ}$ 10252, que reorganiza a estrutura do Instituto Nacional de Colonização e Reforma Agrária (INCRA), extinguindo a Coordenação-Geral de Educação do Campo e Cidadania e subordinando toda e qualquer política agrária ao Ministério da Agricultura, Pecuária e Abastecimento (MAPA). Esse Decreto, ao excluir a Coordenação-Geral, desresponsabiliza qualquer órgão governamental da execução do Pronera, programa pioneiro na oferta de educação superior aos povos do campo. O Decreto representa uma forma discursiva oficial do atual governo, que retira direitos e silencia a voz da educação do campo, antes representada pela Coordenadoria-Geral, agora extinta. A desresponsabilização governamental em relação ao Pronera mostrou que esse não seria mais um programa visto como necessário ou importante, tornando-se assim, sem espaço de ação. Em nota oficial, o Fórum Nacional de Educação do Campo afirmou que esse decreto "extingue o lugar político da elaboração e gestão de uma das maiores políticas públicas de educação, no Brasil” (FONEC, 2020), que buscava articular os sujeitos dos movimentos sociais, sindicais e de trabalhadores e trabalhadoras do campo, com os sujeitos servidores do INCRA e os sujeitos das Universidades.

Em 22 de Setembro de 2020, em discurso oficial ${ }^{5}$ na Assembleia das Nações Unidas (ONU), o presidente da república responsabilizou índios e caboclos pelas intensas queimadas que acontecem na Amazônia. Esse discurso responsabilizou representantes dos povos do campo por atitudes criminosas que vêm devastando a floresta brasileira, tirando o foco e a responsabilidade da atuação governamental e culpabilizando uma minoria, que já vem sendo atacada e desmoralizada continuamente. Em outros momentos esse governante já afirmou que os índios e quilombolas já possuem muitas terras e não permitiria que nenhum centímetro a mais lhes fosse concedido, numa crítica à proteção da demarcação de terras indígenas e quilombolas. Claramente, a responsividade e direcionalidade desse discurso não estão voltadas aos povos indígenas, mas, referendam atitudes criminosas realizadas por extrativistas, grileiros e agropecuaristas que têm se sentido autorizados a cometer tais atos. Segundo o Relatório "Violência Contra os Povos Indígenas do Brasil - Dados de 2019”, elaborado e publicado, em 2020, pelo Conselho Indigenista Missionário (CIMI), no atual governo houve intensificação das expropriações de terras indígenas e um aumento de 134,9\%, em relação a 2018, no registro de casos relacionados a invasões para exploração ilegal de recursos e danos ao patrimônio indígena.

Esses discursos não são únicos e isolados, mas representam o posicionamento oficial governamental sobre os povos do campo. A educação do campo no Brasil foi concebida a partir da realidade dos povos campesinos, construída no diálogo com os movimentos sociais do campo e com as demandas e necessidades desses povos.

5 https://g1.globo.com/politica/noticia/2020/09/22/em-video-gravado-bolsonaro-faz-discurso-na-abertura-daassembleia-da-onu.ghtml 
Qualquer ataque à realidade do campo, mesmo que não seja necessariamente um ataque à educação, mas de perda de direitos, minimização ou sucateamento dos diretos, atinge frontalmente o cerne desse projeto e, consequentemente, propostas, como a nossa, que buscam contribuir para seu avanço. Ainda que as licenciaturas em educação do campo estejam parcialmente protegidas nas estruturas das universidades, sofrendo corte de fomento junto com a instituição, mas não sendo subordinadas diretamente ao governo, sua proposta faz sentido se alinhada a uma concepção de respeito e valorização do campo, suas particularidades e seu povo.

Assim, o maior desafio imposto para a educação científica do campo, atualmente e no futuro, é a luta de forma solidária, pela manutenção dos direitos e pela não deterioração do projeto da educação do campo. Sabemos que a luta pela manutenção de direitos, afirmação e espaço são contínuas e, mesmo antes, se fazia necessária. Mas, quando há ataque aberto e direto, seja em pronunciamentos oficiais ou extraoficiais, essa luta deve ser intensificada e a educação em ciências, enquanto área que mantém alguns privilégios, deve buscar o diálogo e, solidariamente, se unir ao discurso em defesa da educação do campo no nosso país.

\section{Referências Bibliográficas}

Arroyo, M. G., Caldart, R. S., \& Molina, M. C. (2004). Apresentação. In M. G. Arroyo, R. S., Caldart \& M. C. Molina, Por uma Educação do Campo (pp. 7-18). Vozes.

Arroyo, M. G. (2012). Formação de educadores do campo. In R. S., Caldart, I. B., Pereira, P., Alentejano \& G., Frigotto (Orgs.), Dicionário da Educação do Campo (pp. 361-373). Expressão Popular.

Auler, D. (2007). Articulação entre Pressupostos do Educador Paulo Freire e o Movimento CTS: Novos Caminhos para a Educação em Ciências, Contexto e Educação, 22(77), 167 188. https://www.revistas.unijui.edu.br/index.php/contextoeducacao/article/view/1089

Bakhtin, M. M. (Voloshínov, V. N.) (2009). Marxismo e filosofia da linguagem (13ª ed.). Hucitec.

Bakhtin, M. M. (2011). Estética da criação verbal (6ª ed.). WMF Martins Fontes.

Bakhtin, M. M. (2015). Teoria do romance I: A estilística. Editora 34.

Brick, E. M., Pernambuco, M. M. C. A., Silva, A. F. G., \& Delizoicov, D. (2014). Paulo Freire: interfaces entre Ensino de Ciências Naturais e Educação do Campo. In M. C. Molina (Org), Licenciaturas em Educação do Campo e o Ensino de Ciências Naturais: desafios à promoção do Trabalho Docente interdisciplinar (pp. 23-59). MDA.

Caldart, R. S. (2010). Licenciatura em Educação do Campo e projeto formativo: qual o lugar da docência por área?. In R. S. Caldart (Org.), A. R. Fetzner, R. Rodrigues, \& L. C. Freitas, Caminhos para a transformação da escola: reflexões desde práticas da licenciatura em educação do campo (pp. 127-154). Expressão Popular. 
Caldart, R. S. (2012). Educação do Campo. In R. S. Caldart, I. B. Pereira, P. Alentejano, \& G. Frigotto (Orgs.) Dicionário da Educação do Campo (pp. 259-267). Expressão Popular. Cardoso, L. R., \& Araújo, M. I. O. (2012). Currículo de Ciências: professores e escolas do campo. Revista Ensaio - Pesquisa em Educação em Ciências, 14(2), 121-135. https:// doi.org/10.1590/1983-21172013140208

CIMI (2020). Violência Contra os Povos Indígenas no Brasil - Dados de 2019. Relatório Oficial CIMI.

Contreras, J. (2012). A autonomia do professor (2a ed.). Cortez.

Costa, L. G., Aikawa, M. S., \& Cunha, I. S. (2014). Ensino de Ciências: uma discussão na perspectiva da Educação do Campo. Revista Amazônica de Ensino de Ciências, 7(13), 161-169. http://periodicos.uea.edu.br/index.php/arete/article/view/111

Crepalde, R. S., Klepka, V., Pinto, T. H. O., \& Sousa, M. A (2019). A Integração de Saberes e as Marcas dos Conhecimentos Tradicionais: Reconhecer para Afirmar Trocas Interculturais no Ensino de Ciências. Revista Brasileira de Pesquisa em Educação em Ciências, 19, 275-297. https://doi.org/10.28976/1984-2686rbpec2019u275297

Duarte, M. S., Schwartz, L. B., Silva, A. M. T. B., \& Rezende, F. (08-13 de novembro, 2009). Perspectivas para além da racionalidade técnica na formação de professores de Ciências. VII Encontro Nacional de Pesquisa em Educação em Ciências (ENPEC), Florianópolis, Santa Catarina.

Fernandes, B. M. (1999). Por uma educação básica do campo. In M. G. Arroyo, \& B. M. Fernandes, Por uma educação básica do campo: A Educação Básica e o Movimento Social do Campo (pp. 43-55). Articulação Nacional Por uma Educação Básica do Campo.

Fernandes, B. M., Cerioli, P. R., \& Caldart, R. S. (2004). Primeira Conferência Nacional "Por uma Educação do Campo", texto preparatório. In M. G. Arroyo, R. S. Caldart, \& M. C. Molina, Por uma Educação do Campo (pp. 20-63). Vozes.

Fórum Nacional de Educação do Campo - FONEC (2020). Em defesa do Pronera e do direito à Educação do Campo, Nota oficial publicada em 25 de fevereiro de 2020. https:// mst.org.br/2020/02/28/forum-nacional-de-educacao-do-campo-denuncia-extincaodo-pronera/

Freire, P. (1977). Pedagogia do Oprimido (4⿳a ed.). Paz e Terra.

Frigotto, G. (2012) Educação Omnilateral. In R. S. Caldart, I. B. Pereira, P. Alentejano, \& G. Frigotto, Dicionário da Educação do Campo (pp. 267-274). Expressão Popular.

Giroux, H. A. (1997). Os professores como intelectuais: rumo a uma pedagogia crítica da aprendizagem. Artmed.

Halmenschalger, K. R., Fernandes, C. S., Camillo, J., \& Brick, E. M. (2018). Abordagem de temas no Ensino de Ciências e Matemática: um olhar para produções relacionadas à Educação do Campo. Investigações em Ensino de Ciências, 23(2), 172-189. https://www. if.ufrgs.br/cref/ojs/index.php/ienci/article/view/1042 
Krasilchik, M. (2000). Reformas e Realidade o caso do ensino das ciências. São Paulo em Perspectiva, 14(1), 85-93.

Lacey, H. (1998). Valores e Atividade Científica. Discurso Editorial.

Lacey, H. (20-26 de agosto, 1999). As formas nas quais as ciências são e não são livres de valores (Marcos Rodrigues da Silva, Tradutor). $11^{\circ}$ Congresso Internacional de Lógica, Metodologia e Filosofia da Ciência, Cracóvia, 1999.

Lei no 4.024, de 20 de Dezembro de 1961 (1961). Fixa as Diretrizes e Bases da Educação Nacional. https://www2.camara.leg.br/legin/fed/lei/1960-1969/lei-4024-20-dezembro1961-353722-publicacaooriginal-1-pl.html

Lei $n^{\circ} 5.692$, de 11 de Agosto de 1971 (1971). Fixa Diretrizes e Bases para o ensino de $1^{\circ} e$ $2^{\circ}$ graus, e dá outras providências. https://www2.camara.leg.br/legin/fed/lei/1970-1979/ lei-5692-11-agosto-1971-357752-publicacaooriginal-1-pl.html

Lei 9.394, de 20 de Dezembro de 1996 (1996). Estabelece as Diretrizes e Bases da educação nacional. http://www.planalto.gov.br/ccivil_03/leis/19394.htm

Locatelli, A., Santos, K. F., \& Rosa, C. T. W. (2020). Atividades Experimentais com enfoque em Agroecologia na perspectiva da Educação do Campo. Areté - Revista Amazônica de Ensino de Ciências, 13(27), 1-16. http://periodicos.uea.edu.br/index.php/ arete/article/view/1832

Michelotti, F. (2008). Educação do Campo: reflexões a partir da tríade ProduçãoCidadania-Pesquisa. In C. A. Santos, Por uma Educação do Campo: Campo - Políticas Públicas - Educação (pp. 87-96). INCRA/MDA.

Molina, M. C. (2015). A educação do campo e o enfrentamento das tendências das atuais políticas públicas. Educação em Perspectiva, 6(2), 378-400. https://periodicos.ufv. br/educacaoemperspectiva/article/view/6809

Molina, M. C., \& Sá, L. M. (2012). Licenciatura em Educação do Campo. In R. S. Caldart, I. B. Pereira, P. Alentejano, \& G., Frigotto (Orgs.), Dicionário da Educação do Campo (pp. 468-474). Expressão Popular.

Molina, M. C., \& Hage, S. M. (2015). Política de formação de educadores do campo no contexto da expansão da educação superior. Revista Educação em questão, 51(37), 121-146. https://doi.org/10.21680/1981-1802.2015v51n37ID7174

Nardi, R. (2014). Memórias do ensino de Ciências no Brasil: a constituição da área segundo pesquisadores brasileiros, origens e avanços da pós-graduação. Revista do Imea, 2(2), 13-46. https://revistas.unila.edu.br/index.php/IMEA-UNILA/article/view/341

Palacios, E. M. G., von Linsingen, I., Galbarte, J. C. G., Cerezo, J. A. L., Luján, J. L., Pereira, L. T. V., Gordillo, M. M., Valdés, C., Bazzo, W. A. (2003). Introdução aos Estudos CTS (Ciência, Tecnologia e Sociedade). Organização dos Estados Ibero-americanos para a Educação, a Ciência e a Cultura (OEI). 
Paniago, R. N., Rocha, S. A., \& Paniago, J. N. (2014). A pesquisa como possibilidade de ressignificação das práticas de ensino na escola do/no campo. Revista Ensaio - Pesquisa em Educação em Ciências, 16(1), 171-188.

Resolução CNE/ CEB 1, de 3 de Abril de 2002 (2002). Institui Diretrizes Operacionais para a Educação Básica nas Escolas do Campo. http://pronacampo.mec.gov.br/images/ pdf/mn_resolucao_\%201_de_3_de_abril_de_2002.pdf

Ribeiro, M. (2013). Formação de educadores de jovens e adultos do campo: quase tudo por fazer. Revista Perspectiva, 31(2), 479-504.

Ribeiro, M. (2015). Terra, trabalho, educação: relações que projetam desafios à educação do campo. Educação em Perspectiva, 6(2), 268-289.

Rosa, S. E., \& Auler, D. (2016). Não neutralidade da Ciência-Tecnologia: problematizando silenciamentos em práticas educativas CTS. Alexandria - Revista de Educação em Ciência e Tecnologia, 9(2), 203-231. https://doi.org/10.5007/1982-5153.2016v9n2p203

Roso, C. C., Santos, R. A., Rosa, S. E., \& Auler, D. (2015). Currículotemático fundamentado em FREIRE-CTS: engajamento de professores de Física em formação inicial. Ensaio - Pesquisa em Educação em Ciências, 17(2), 372-389. https://doi.org/10.1590/198321172015170205

Santos, W. L. P., \& Mortimer, E. F. (2002). Uma análise de pressupostos teóricos da abordagem C-T-S (Ciência - Tecnologia - Sociedade) no contexto da educação brasileira. Ensaio - Pesquisa em Educação em Ciências, 2(2), 1-23. https://doi. org/10.1590/1983-21172000020202

Santos, B. S. (2007). Renovar a teoria crítica e reinventar a emancipação social. Boitempo.

Santos, W. L. P. (2008). Educação Científica Humanística em uma Perspectiva Freireana: Resgatando a Função do Ensino de CTS. Alexandria - Revista de Educação em Ciência e Tecnologia, 1(1), 109-131. https://periodicos.ufsc.br/index.php/alexandria/article/ view/37426

Santos, B. S. (2018). Construindo as Epistemologias do Sul: Antologia Essencial, Volume II: Para um pensamento alternativo de alternativas. In M. P. Meneses, J. A. Nunes, C. L. Añón, A. A. Bonet, \& N. L. Gomes (Orgs.). CLACSO.

Silva, A. B., Zang, C., Paludo, C., Camini, I., Cover, M., Luz, M. F., \& Reichenbach, V. (2006). Formação de educadores e educadoras do e no campo. In R. S. Caldart, C. Paludo, \& J. Doll (Org.), Como se formam os sujeitos do campo? Idosos, adultos, jovens, crianças e educadores (pp. 141-157). NEAD.

Silva, T. T. (2017). Documentos de identidade. Autêntica Editora.

Silva, F. N. S., Lima, L. R. F. C., Moradillo, E. F., \& Massena, E. P. (2019). Educação do campo e ensino de ciências no Brasil: uma revisão doa últimos dez anos. Revista Brasileira de Ensino de Ciência e Tecnologia, 12(1), 221-239. http://dx.doi.org/10.3895/ rbect.v12n1.7547 
Silveira, I. G. (2011). A educação na ponte campo-cidade: saberes necessários à formação do professor. Educação em Perspectiva, 2(1), 78-97. https://periodicos.ufv.br/ educacaoemperspectiva/article/view/6488

Souza, J.; Ostermann, F.; Rezende, F. (2020). Educação do campo na voz da pesquisa em educação em ciências. Ensaio - Pesquisa em Educação em Ciências, 22, 1-20. https:// doi.org/10.1590/21172020210107

Souza, J. (2020). Uma proposta de educação científica para a formação do docente do campo (Tese de Doutorado, Instituto de Física da Universidade Federal do Rio Grande do Sul, Porto Alegre, Rio Grande do Sul). LUME - Repositório Digital (UFRGS). http:// hdl.handle.net/10183/217486

Tolbert, S., \& Bazzul, J. (2017) Toward the sociopolitical in Science Education. Cultural Studies of Science Education, 12(2), 321-330.

Vendramini, C. R. (2013). Os desafios do MST e da educação na atualidade brasileira. Perspectiva, 31(2), 505-525.

Veneu, A. A., Ferraz, G., \& Rezende, F. (2015). Análise de discursos no ensino de ciências: considerações teóricas, implicações epistemológicas e metodológicas. Ensaio - Pesquisa em Educação em Ciências, 17(1), 126-149. 
Josiane de Souza

Instituto Federal Sul-rio-grandense Santana do Livramento, Rio Grande do Sul, Brasil josiane.zilios@gmail.com

Fernanda Ostermann

Universidade Federal do Rio Grande do Sul Porto Alegre, Rio Grande do Su, Brasil fernandaostermann@ufrgs.br

Flavia Rezende

Universidade Federal do Rio Grande do Sul Porto Alegre, Rio Grande do Sul, Brasil flaviarezende@uol.com.br

Editor Responsável

Cristiano Barbosa de Moura

Manifestação de Atenção às Boas Práticas Científicas e de Isenção de Interesse

Os autores declaram ter cuidado de aspectos éticos ao longo do desenvolvimento da pesquisa e não ter qualquer interesse concorrente ou relações pessoais que possam ter influenciado o trabalho relatado no texto. 